\title{
STUDI KRITIKALITAS VHTR PRISMATIK SEBAGAI FUNGSI RADIUS BAHAN BAKAR KOMPAK DAN KERNEL
}

\section{STUDY ON PRISMATIC VHTR CRITICALITY AS A FUNCTION OF FUEL COMPACT AND KERNEL RADIUS}

\author{
Fajar Arianto \\ Departemen Fisika - Institut Teknologi Bandung \\ Jalan Ganesha No. 10, Bandung 40132 \\ Tel. (022)2500834, Fax. (022)2506452, \\ Jurusan Fisika - Universitas Diponegoro \\ Jalan Prof. Soedarto, S.H., Tembalang, Semarang 50275 \\ e-mail: ariantofajar@gmail.com \\ Suwoto, Zuhair \\ Pusat Teknologi Reaktor dan Keselamatan Nuklir - BATAN \\ Kawasan Puspiptek, Gedung No. 80, Serpong, Tangerang 15310 \\ Tel. (021)7560912, Fax. (021)7560913
}

Diterima 28 Pebruari 2013, diterima dalam bentuk perbaikan 31 Mei 2013, disetujui 05 Juni 2013

\begin{abstract}
ABSTRAK
STUDI KRITIKALITAS VHTR PRISMATIK SEBAGAI FUNGSI RADIUS BAHAN BAKAR KOMPAK DAN KERNEL. Radius bahan bakar kompak dan kernel selama ini dibuat tetap pada nilai baku yang diadopsi oleh proyek reaktor suhu tinggi. Radius kompak bahan bakar ditetapkan 0,6225 cm dan radius kernel bahan bakar ditentukan 0,0250 cm. Dua parameter ini diinvestigasi karena sangat mempengaruhi performa moderasi neutron dalam teras VHTR. Efek radius kernel dan bahan bakar kompak dalam bahan bakar blok VHTR sebagai representasi dari teras aktif didiskusikan dalam makalah ini. Pengkayaan ${ }^{235} \mathrm{U}$ sebesar $12 \%$ dan fraksi packing TRISO 0,29 dikerjakan di seluruh perhitungan dengan program transport Monte Carlo MCNPX dan pustaka data nuklir energi kontinu ENDF/B-VII pada suhu 1200K. Bahan bakar blok VHTR dimodelkan secara utuh dan presisi dengan kondisi batas reflektif. Hasil perhitungan memperlihatkan ketergantungan $k_{\infty}$ pada radius kernel berkurang seiring dengan berkurangnya radius bahan bakar kompak. Nilai $k_{\infty}$ hampir tidak bergantung pada radius kernel untuk radius bahan bakar kompak 0,4000 cm. Analisis menyimpulkan bahwa, kombinasi dua parameter ini adalah cara yang tepat untuk mendapatkan nilai faktor perlipatan neutron tak hingga yang diinginkan dari teras VHTR prismatik dengan fraksi packing dan pengkayaan bahan bakar yang spesifik.
\end{abstract}

Kata Kunci: TRISO, kernel, bahan bakar kompak, bahan bakar blok, VHTR

\begin{abstract}
STUDY ON PRISMATIC VHTR CRITICALITY AS A FUNCTION OF FUEL COMPACT AND KERNEL RADIUS. Radius of fuel compact and kernel until now are fixed for standard value adopted by project of high suhue reactor. Radius of fuel compact is set $0.6225 \mathrm{~cm}$ and radius of kernel is determined 0.0250 . These two parameters are investigated because of their effects on the performance of neutron moderation in the VHTR core. Effect of kernel and fuel compact radiuses on the VHTR fuel block as a representation of the active core are discussed in this paper. ${ }^{235} \mathrm{U}$ enrichment of $12 \%$ and TRISO packing fraction of 0.29 were carried out in all calculations with Monte Carlo transport code MCNPX and continuous energy nuclear data library ENDF/B-VII at a suhue of 1200K. VHTR fuel blocks are modeled as a whole and precision with reflective boundary conditions. The calculation result shows that the dependence of $k_{\infty}$ on the radius of kernel decreases with reducing of fuel compact radius. The value of $k_{\infty}$ almost does not depend on the kernel radius for a compact fuel radius of $0.4000 \mathrm{~cm}$. The analysis concluded that, the combination of these two parameters is the right way to get the desirable infinite neutron multiplication factor of the prismatic VHTR core with specific packing fraction and fuel enrichment.
\end{abstract}

Keywords: TRISO, kernel, fuel compact, fuel block, VHTR 


\section{PENDAHULUAN}

Deaktor suhu sangat tinggi VHTR ${ }^{(1)}$ merupakan salah satu dari enam kandidat konsep sistem reaktor Generasi $I^{(2)}$ yang didesain untuk pembangkit listrik dan produksi hidrogen. VHTR adalah desain yang memenuhi persyaratan keekonomian, keselamatan pasif, kesinambungan, resistansi proliferasi dan proteksi fisik. Teknologi VHTR didasarkan pada konsep yang dikembangkan untuk reaktor Fort St. Vrain dan Peach Bottom USA, maupun pada pengalaman internasional yang ekstensif dari fasilitas AVR dan THTR Jerman, PROTEUS ${ }^{(3)}$ Swiss, HTR-10(4) China, HTTR ${ }^{(5)}$ Jepang serta GROG ${ }^{(6)}$ dan ASTRA ${ }^{(7)}$ Rusia.

Konsep desain VHTR adalah reaktor dengan efisiensi tinggi dan kapabilitas produksi listrik dan panas proses untuk spektrum luas dari suhu tinggi dan proses energi intensif. VHTR memasok panas dengan suhu outlet pendingin helium teras hingga $1000^{\circ} \mathrm{C}$. Sejauh ini terdapat dua tipe konsep desain VHTR yaitu tipe berbahan bakar prismatik dan tipe berbahan bakar pebble-bed. Kedua desain ini menggunakan partikel TRISO yang berdiameter 0,78-0,92 mm. Partikel TRISO terdistribusi secara acak dalam bahan bakar kompak untuk desain prismatik dan dalam bahan bakar pebble untuk desain pebble-bed.

Pengembangan konsep VHTR selain ditujukan untuk daya listrik efisiensi tinggi dan aplikasi panas proses suhu tinggi, juga untuk studi siklus bahan bakar VHTR yang meliputi pemanfaatan bahan bakar bekas reaktor air ringan (light water reactor, LWR) daur ulang bahan bakar bekas VHTR, pemanfaatan VHTR dalam manajemen TRU dan performa penyimpanan geologi bahan bakar bekas VHTR. Namun parameter desain seperti pengkayaan bahan bakar dan fraksi packing partikel TRISO, termasuk radius bahan bakar kompak dan kernel selama ini dibuat tetap pada nilai baku yang diadopsi oleh proyek reaktor suhu tinggi. Radius bahan bakar kompak ditetapkan 0,6225 cm dan radius kernel bahan bakar ditentukan $0,0250 \mathrm{~cm}$.

Dua parameter ini diinvestigasi karena sangat mempengaruhi performa moderasi neutron dalam teras VHTR prismatik. Efek radius bahan bakar kompak dan kernel dalam bahan bakar blok VHTR sebagai representasi dari teras aktif didiskusikan dalam makalah ini. Pengkayaan ${ }^{235} \mathrm{U}$ sebesar $12 \%$ dan fraksi packing TRISO 0,29 dikerjakan di seluruh perhitungan pada suhu 1200K dengan program transport Monte Carlo MCNPX ${ }^{(8)}$. Bahan bakar blok VHTR dimodelkan secara utuh dan presisi dengan kondisi batas reflektif. Pustaka data nuklir energi kontinu ENDF/B-VII ${ }^{(9)}$ dimanfaatkan untuk melengkapi analisis kritikalitas VHTR prismatik sebagai fungsi radius bahan bakar kompak dan kernel.

\section{METODOLOGI}

\section{Deskripsi Bahan Bakar VHTR Prismatik}

Bahan bakar blok VHTR dikomposisi dengan 222 bahan bakar kompak dan 109 kanal pendingin. Setiap kanal pendingin atau bahan bakar kompak berada dalam sebuah kisi heksagonal dengan dimensi flat to flat $1,8796 \mathrm{~cm}$. Sebanyak 22.318 partikel TRISO yang terdispersi dalam matriks grafit dimuatkan ke dalam bahan bakar kompak silindris berdiameter 1,2450 $\mathrm{cm}$. Bahan bakar kompak silindris dimasukkan ke dalam lubang vertikal yang berada di pusat moderator grafit heksagonal. Kanal pendingin helium berdiameter $1,5876 \mathrm{~cm}$ juga diposisikan di pusat moderator grafit heksagonal.

Tabel 1. Dimensi partikel TRISO dan bahan bakar kompak VHTR ${ }^{(10)}$.

\begin{tabular}{|c|c|c|c|c|c|}
\hline \multirow{5}{*}{ 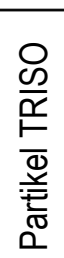 } & & Radius (cm) & \multirow{2}{*}{$\begin{array}{l}\text { Bahan bakar } \\
\text { kompak }\end{array}$} & Radius (cm) & Tinggi $(\mathrm{cm})$ \\
\hline & Kernel & 0,0175 & & 0,6225 & 4,5553 \\
\hline & Buffer & 0,0275 & \multirow{2}{*}{$\begin{array}{l}\text { Kanal } \\
\text { pendingin }\end{array}$} & Radius (cm) & Tinggi $(\mathrm{cm})$ \\
\hline & $\mathrm{IPyC}$ & 0,0315 & & 0,7938 & 4,5553 \\
\hline & $\mathrm{SiC}$ & 0,0350 & Blok grafit & Pitch $(\mathrm{cm})$ & Tinggi (cm) \\
\hline
\end{tabular}

Partikel TRISO terdistribusi secara acak dalam bahan bakar kompak dengan fraksi packing $29 \%$. Partikel ini terdiri dari kernel uranium oksikarbida (UCO) berpengkayaan ${ }^{235} \mathrm{U} 12 \%$ yang dilapisi oleh empat lapisan. Lapisan terdiri dari penyangga karbon berpori ( $\mathrm{C}$, buffer) densitas rendah yang berbatasan dengan kernel bahan bakar yang diikuti oleh pirokarbon dalam (IPyC, inner pyrolitic carbon) densitas tinggi, silikon karbida (SiC) dan pirokarbon luar (OPyC, outer pyrolitic carbon) densitas tinggi pula. Lapisan TRISO berfungsi sebagai penahan 
mekanik maupun penahan produk fisi dari reaksi nuklir di dalam bahan bakar kernel. Tabel 1 memperlihatkan dimensi partikel TRISO dan bahan bakar kompak VHTR. Skema geometri partikel TRISO, bahan bakar kompak dan bahan bakar blok VHTR dengan jarak antara dua permukaan flat 35,81 cm dan tinggi $79,3 \mathrm{~cm}$ diperlihatkan pada Gambar 1.

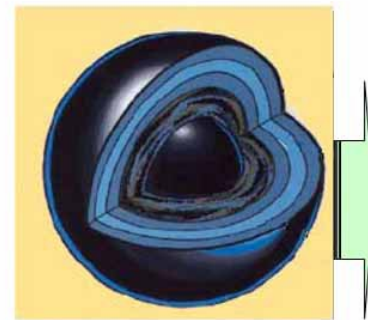

partikel berlapis TRISO

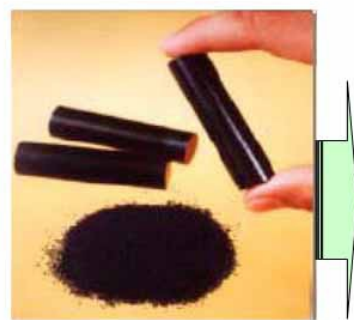

bahan bakar kompak

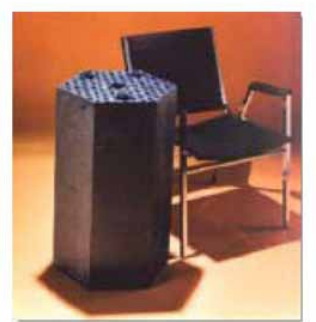

bahan bakar blok

Gambar 1. Skema geometri partikel TRISO, bahan bakar kompak dan bahan bakar blok VHTR ${ }^{(1)}$.

\section{Model Perhitungan MCNPX}

Pemodelan konfigurasi geometrik dari reaktor secara efisien dan presisi memegang peranan penting dalam perhitungan neutronik. Model harus dibuat sedekat mungkin dengan geometri nyata, dimana komposisi dan densitas material harus benar-benar akurat. Model juga harus mempertimbangkan heterogenitas ganda dan distribusi stokastik dari partikel bahan bakar.

Mengambil kelebihan kapabilitas MCNPX untuk pemodelan geometri struktur kisi, pemodelan bahan bakar blok VHTR mengikuti progresi geometri dari partikel TRISO hingga bahan bakar blok seperti ditunjukkan dalam Gambar 2. Pemodelan dimulai dari kisi tunggal partikel TRISO yang terdiri atas matriks grafit kubik dimana partikel TRISO ditempatkan di pusat kisi. Kisi kubik ini memiliki bahan bakar kernel yang dikelilingi oleh empat lapisan coating. Bahan bakar kernel adalah heterogenitas pertama. Dalam MCNPX, kisi partikel TRISO dibangun oleh sel-sel permukaan bola konsentris yang ukurannya ditunjukkan pada Tabel 1 dengan komposisi dan densitas atom seperti ditunjukkan pada Tabel 2.

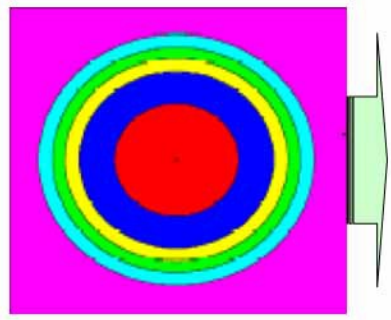

partikel berlapis TRISO

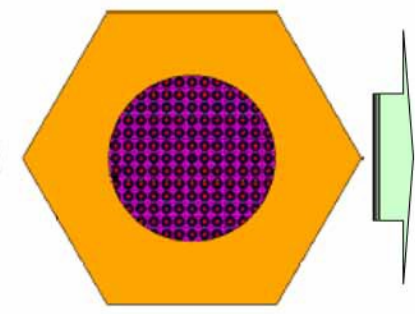

bahan bakar kompak

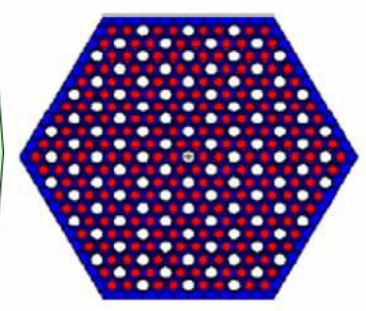

bahan bakar blok

Gambar 2. Progresi geometri dari partikel TRISO hingga bahan bakar blok VHTR ${ }^{(10)}$.

Tabel 2. Densitas atom partikel TRISO dan matriks grafit ${ }^{(10)}$.

\begin{tabular}{lcccc}
\hline & Komposisi & Densitas $\left(\mathrm{g} / \mathrm{cm}^{3}\right)$ & Nuklida & $\begin{array}{c}\text { Densitas atom } \\
\text { (atom/barn.cm) }\end{array}$ \\
\hline Kernel & U C.5 01.5 & 10,5 & $235 \mathrm{U}$ & $2,4749 \times 10^{-3}$ \\
& & & $238 \mathrm{U}$ & $2,1142 \times 10^{-2}$ \\
& & & $12 \mathrm{C}$ & $1,1808 \times 10^{-2}$ \\
& $12 \mathrm{C}$ & 1,0 & $16 \mathrm{C}$ & $3,5426 \times 10^{-2}$ \\
\hline Buffer & $12 \mathrm{C}$ & 1,9 & $12 \mathrm{C}$ & $5,0183 \times 10^{-2}$ \\
\hline IPyC & SiC & 3,2 & $28 \mathrm{Si}$ & $9,5348 \times 10^{-2}$ \\
\hline Silikon karbida & & & $12 \mathrm{C}$ & $4,8060 \times 10^{-2}$ \\
& $12 \mathrm{C}$ & 1,9 & $12 \mathrm{C}$ & $9,8060 \times 10^{-2}$ \\
\hline OPyC & $12 \mathrm{C}$ & 1,7 & $12 \mathrm{C}$ & $8,5348 \times 10^{-2}$ \\
\hline Matriks grafit & & & &
\end{tabular}


Jurnal Iptek Nuklir Ganendra

Ganendra Journal of Nuclear Science and Technology

Vol. 16 No. 2 Juli 2013: 59-65

Untuk menginvestigasi efek radius bahan bakar kernel, pemodelan kisi tunggal partikel TRISO dikerjakan pada berbagai radius kernel. Tabel 3 menyajikan ukuran pitch kisi partikel TRISO $(p)$ yang diperoleh dari hubungan,

$$
p=R_{\text {TRISO }} * \sqrt[3]{\frac{4 \pi}{3 f}}
$$

dengan $\mathrm{R}_{\mathrm{TRISO}}$ dan $f$ masing-masing adalah radius dan fraksi packing partikel TRISO $(=0,29)$.

Tabel 3. Ukuran pitch sel kisi partikel TRISO.

\begin{tabular}{ccc}
\hline Radius kernel $(\mathrm{cm})$ & Radius TRISO $(\mathrm{cm})$ & Pitch sel kisi $(p, \mathrm{~cm})$ \\
\hline 0,0175 & 0,0390 & 0,094992 \\
0,0200 & 0,0415 & 0,101081 \\
0,0225 & 0,0440 & 0,107170 \\
0,0250 & 0,0465 & 0,113260 \\
0,0275 & 0,0490 & 0,119349 \\
0,0300 & 0,0515 & 0,125438 \\
\hline
\end{tabular}

Langkah selanjutnya adalah memodelkan bahan bakar kompak dengan kisi heksagonal. Bahan bakar kompak merupakan heterogenitas kedua. Kisi heksagonal bahan bakar kompak dikonstruksi dengan membuat LAT $=2$ dan FILL pada kisi kubik TRISO dengan pitch heksagonal 1,8796 cm dan dikerjakan pada radius silindris 0,$4000 ; 0,5000 ; 0,6225 ; 0,7000 ; 0,8000$ dan $0,9000 \mathrm{~cm}$.

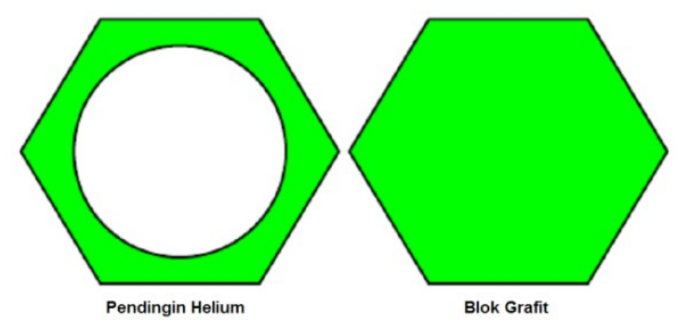

Gambar 3. Model kisi heksagonal pendingin helium dan blok grafit ${ }^{(10)}$.

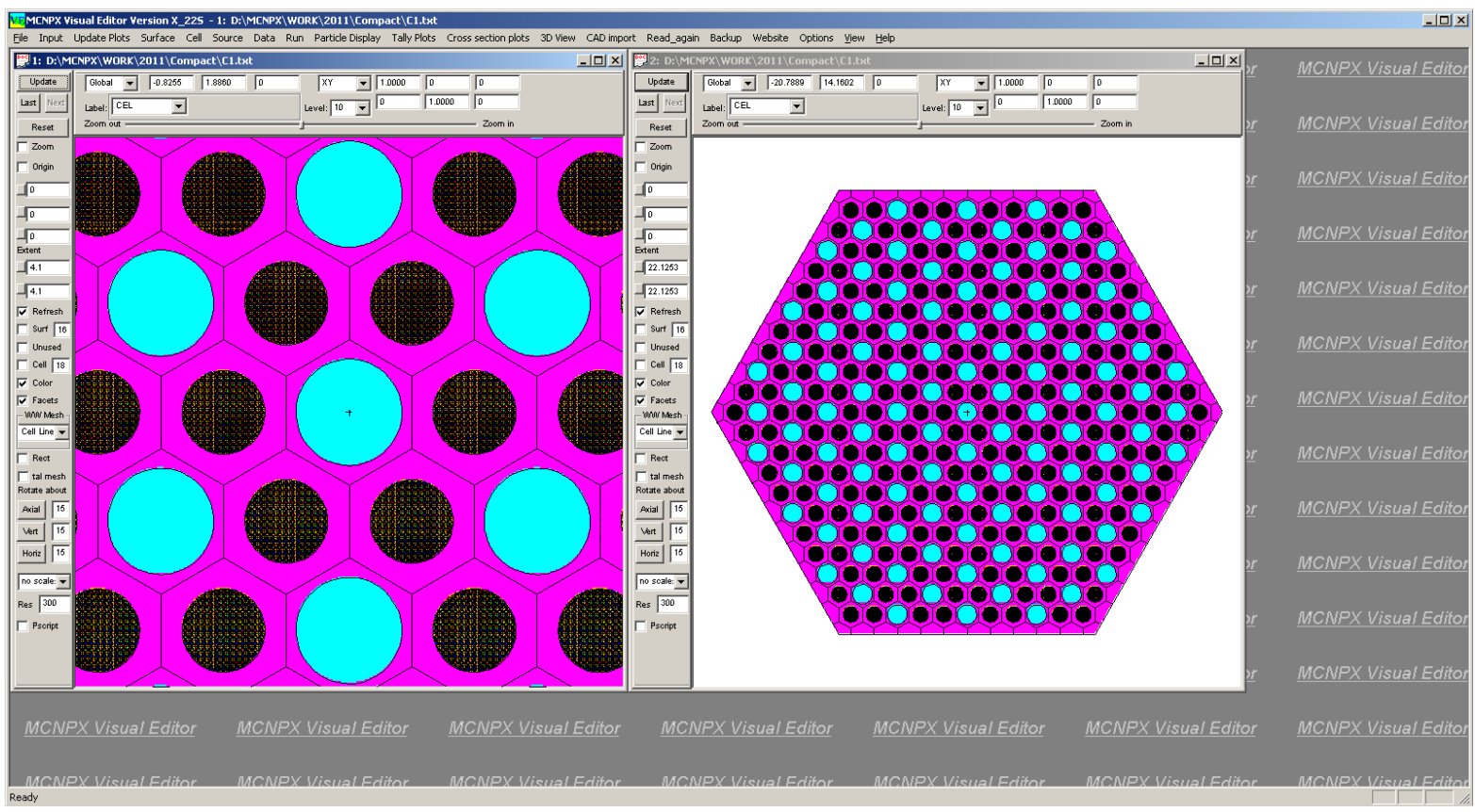


Gambar 4. Model MCNPX untuk kisi bahan bakar blok VHTR.

Kanal pendingin helium dimodelkan dengan kisi heksagonal yang sama. Model kisi ini didefinisikan dengan membuat LAT = 2 dan FILL pada kisi silindris helium. Di sekeliling bahan bakar blok VHTR dimuatkan blok grafit yang dimodelkan dengan kisi heksagonal yang sama pula. Model kisi heksagonal pendingin helium dan blok grafit diperlihatkan dalam Gambar 3. Kisi kanal pendingin, kisi bahan bakar kompak dan kisi blok grafit disusun sedemikian rupa dengan membuat array baris dan kolom untuk membentuk kisi bahan bakar blok seperti diperlihatkan dalam Gambar 4. Densitas atom blok grafit dengan impuritas boron dan densitas atom pendingin helium diberikan dalam Tabel 4.

Tabel 4. Densitas atom blok grafit dan pendingin helium ${ }^{(10)}$.

\begin{tabular}{|c|c|c|c|c|}
\hline & Komposisi & Densitas $\left(\mathrm{g} / \mathrm{cm}^{3}\right)$ & Nuklida & $\begin{array}{l}\text { Densitas atom } \\
\text { (atom/barn.cm) }\end{array}$ \\
\hline \multirow{3}{*}{ Blok grafit } & \multirow{3}{*}{$12 \mathrm{C}$} & \multirow{3}{*}{1,74} & $12 \mathrm{C}$ & $8,7241 \times 10^{-2}$ \\
\hline & & & $10 \mathrm{~B}$ & $1,4369 \times 10^{-7}$ \\
\hline & & & $11 \mathrm{~B}$ & $5,7838 \times 10^{-7}$ \\
\hline \multirow{2}{*}{ Pendingin helium } & \multirow{2}{*}{$\mathrm{He}$} & \multirow{2}{*}{ - } & $3 \mathrm{He}$ & $3,7122 \times 10^{-11}$ \\
\hline & & & $4 \mathrm{He}$ & $2,6515 \times 10^{-5}$ \\
\hline
\end{tabular}

\section{HASIL DAN PEMBAHASAN}

Dalam perhitungan ini, MCNPX memanfaatkan pustaka data nuklir energi kontinu ENDF/B-VII untuk memprediksi faktor perlipatan neutron tak hingga $\left(k_{\infty}\right)$ bahan bakar blok VHTR. MCNPX adalah program transport Monte Carlo yang memiliki kapabilitas pemodelan heterogenitas material dan sistem reaktor 3-D dengan geometri yang kompleks. Sebanyak 5.000 histori neutron per siklus dengan total 100 siklus aktif disimulasikan yang menghasilkan deviasi standard dalam $k_{\infty}$ lebih kecil dari 0,12\%. Skipping 10 siklus dikerjakan untuk menghindari konvergensi sumber. Sumber neutron fisi awal dilokasikan di pusat silindris bahan bakar kompak. Data hamburan termal $S(\alpha, \beta)$ graph.01t diaplikasikan untuk mempertimbangkan efek binding yang mempengaruhi interaksi neutron termal dengan seluruh material yang mengandung grafit pada energi di bawah $\sim 4 \mathrm{eV}$.

Tabel 5 memperlihatkan hasil perhitungan faktor perlipatan neutron tak hingga $\left(k_{\infty}\right)$ dari bahan bakar blok VHTR sebagai fungsi radius kernel dan bahan bakar kompak. Jelajah yang cukup luas dari radius kernel bahan bakar secara teknis mempertimbangkan posibilitas digunakannya kernel dengan ukuran radius tertentu untuk insinerasi plutonium dan aktinida minor atau tujuan khusus lainnya. Dari Tabel 5 dapat diamati, untuk radius bahan bakar kompak yang sama, nilai $k_{\infty}$ pada awalnya tinggi kemudian menurun perlahan dengan bertambahnya radius kernel. Ini berarti selain pada radius bahan bakar kompak, $k_{\infty}$ sangat bergantung pada radius kernel. Ketergantungan $k_{\infty}$ menjadi lebih jelas bila hasil perhitungan $k_{\infty}$ dalam Tabel 5 diplot ke dalam grafik seperti diliustrasikan dalam Gambar 5 dan 6.

Tabel 5. Hasil perhitungan $k_{\infty}$ sebagai fungsi radius kernel dan bahan bakar kompak.

\begin{tabular}{|c|c|c|c|c|c|c|}
\hline \multirow{2}{*}{$\begin{array}{l}\text { Radius kompak } \\
(\mathrm{cm})\end{array}$} & \multicolumn{6}{|c|}{$K_{\infty}$ untuk radius kernel $(\mathrm{mm})$ : } \\
\hline & 0,175 & 0,200 & 0,225 & 0,250 & 0,275 & 0,300 \\
\hline & 1,51243 & 1,51203 & 1,50563 & 1,50459 & 1,49426 & 1,49246 \\
\hline 0,4000 & $\pm 0,00111$ & $\pm 0,00094$ & $\pm 0,00117$ & $\pm 0,00084$ & $\pm 0,00099$ & $\pm 0,00106$ \\
\hline & 1,48012 & 1,47479 & 1,44912 & 1,41977 & 1,40645 & 1,40330 \\
\hline 0,5000 & $\pm 0,00101$ & $\pm 0,00101$ & $\pm 0,00103$ & $\pm 0,00098$ & $\pm 0,00107$ & $\pm 0,00109$ \\
\hline & 1,40132 & 1,37035 & 1,34195 & 1,30444 & 1,27010 & 1,26844 \\
\hline 0,6225 & $\pm 0,00100$ & $\pm 0,00111$ & $\pm 0,00118$ & $\pm 0,00100$ & $\pm 0,00113$ & $\pm 0,00104$ \\
\hline & 1,33695 & 1,30953 & 1,25747 & 1,22882 & 1,20765 & 1,17682 \\
\hline 0,7000 & $\pm 0,00113$ & $\pm 0,00129$ & $\pm 0,00110$ & $\pm 0,00126$ & $\pm 0,00115$ & $\pm 0,00119$ \\
\hline & 1,26169 & 1,21603 & 1,16628 & 1,13951 & 1,10802 & 1,07838 \\
\hline 0,8000 & $\pm 0,00109$ & $\pm 0,00111$ & $\pm 0,00106$ & $\pm 0,00108$ & $\pm 0,00111$ & $\pm 0,00109$ \\
\hline 0,9000 & 1,17906 & 1,13762 & 1,08765 & 1,05984 & 1,02874 & 1,00350 \\
\hline
\end{tabular}




$\begin{array}{llllll} \pm 0,00116 & \pm 0,00120 & \pm 0,00110 & \pm 0,00102 & \pm 0,00094 & \pm 0,00094\end{array}$

Gambar 5 memperlihatkan radius bahan bakar kompak yang besar menghasilkan $k_{\infty}$ rendah. Tendensi ini disebabkan pertambahan radius bahan bakar kompak menyebabkan rasio grafit-uranium berkurang yang konsekuensinya mengakibatkan moderasi neutron berkurang. Efek serupa pada $k_{\infty}$ ditunjukkan oleh radius bahan bakar kernel seperti diperlihatkan dalam Gambar 6 . Radius kernel yang besar menghasilkan $k_{\infty}$ rendah karena radius kernel yang besar menyebabkan banyak uranium yang dimuatkan dan grafit menjadi sedikit keberadaannya di dalam bahan bakar kompak. Hal ini mengakibatkan moderasi neutron berkurang dan implikasinya nilai $k_{\infty}$ menjadi rendah.

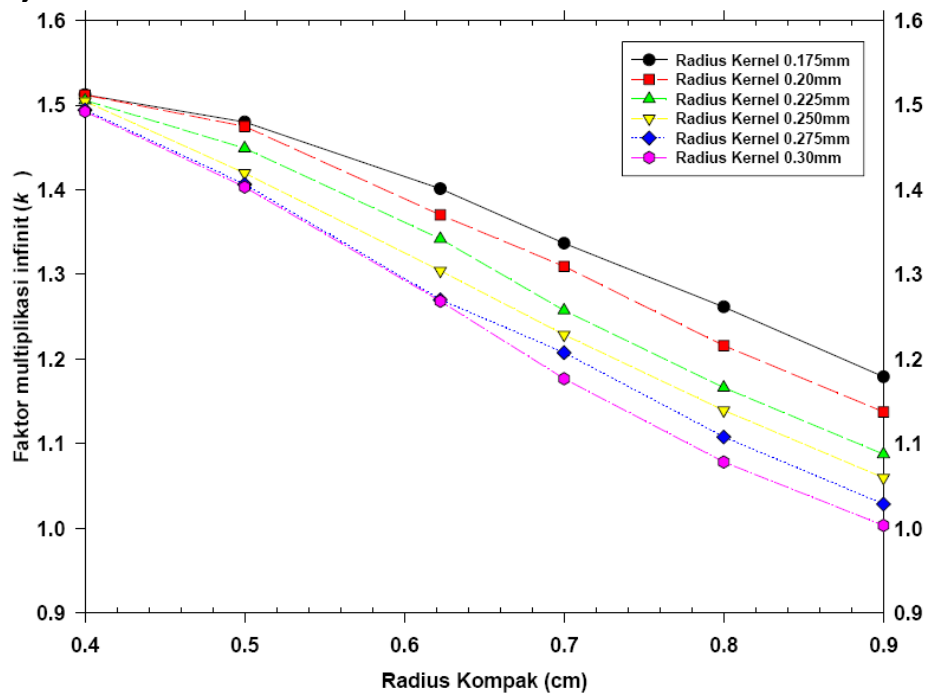

Gambar 5 . Kurva $k_{\infty}$ sebagai fungsi radius bahan bakar kompak untuk berbagai radius kernel.

Gambar 6. Kurva $k_{\infty}$ sebagai fungsi radius kernel untuk berbagai radius bahan bakar kompak.

Hasil-hasil ini mengkonfirmasikan ukuran radius bahan bakar kompak dan kernel dapat mengubah rasio bahan bakar-moderator (F/M) di dalam bahan bakar blok dan implikasinya akan mengubah faktor perlipatan neutron tak hingga secara bersamaan. Namun, efek penting yang bisa diamati pada performa neutronik bahan bakar blok VHTR adalah ketergantungan $k_{\infty}$ pada radius kernel berkurang seiring dengan berkurangnya radius bahan bakar kompak. Dalam bahan bakar kompak dengan radius $0,4000 \mathrm{~cm}$, jumlah kernel tidak berubah secara 
signifikan dengan bertambahnya radius kernel. Sebagai akibatnya, rasio F/M dalam bahan bakar blok hampir tetap, moderasi neutron menjadi konstan dan konsekuensinya nilai $k_{\infty}$ hampir tidak bergantung pada radius kernel untuk radius bahan bakar kompak $0,4000 \mathrm{~cm}$.

\section{KESIMPULAN}

Studi kritikalitas VHTR prismatik sebagai fungsi radius bahan bakar kompak dan kernel telah dilakukan. Pengkayaan ${ }^{235} \mathrm{U}$ sebesar $12 \%$ dan fraksi packing TRISO 0,29 dikerjakan di seluruh perhitungan dengan program transport Monte Carlo MCNPX dan pustaka data nuklir energi kontinu ENDF/B-VII pada suhu 1200K. Hasil perhitungan memperlihatkan radius kernel yang besar menghasilkan $k_{\infty}$ rendah, demikian pula radius bahan bakar kompak yang besar menghasilkan $k_{\infty}$ rendah. Ketergantungan $k_{\infty}$ pada radius kernel berkurang seiring dengan berkurangnya radius bahan bakar kompak. Nilai $k_{\infty}$ hampir tidak bergantung pada radius kernel untuk radius bahan bakar kompak $0,4000 \mathrm{~cm}$. Analisis menyimpulkan bahwa, kombinasi dua parameter ini adalah cara yang tepat untuk mendapatkan nilai faktor perlipatan neutron tak hingga yang diinginkan dari teras VHTR prismatik dengan fraksi packing dan pengkayaan bahan bakar yang spesifik.

\section{DAFTAR PUSTAKA}

FY 2006 Ten-Year Program Plan Appendix 1.0 Next Generation Nuclear Plant, (2006)

, A Technology Roadmap for Generation IV Nuclear Energy Systems, US DOE Nuclear Energy and the Generation IV International Forum (GIF), (2002)

T. WILLIAMS, LEU-HTR PROTEUS: Configuration Descriptions and Critical Balances for the Cores of the HTR-PROTEUS Experimental Programme, Paul Schrerrer Institute, Report TM-41-95-18, (1996)

S. HU, R. WANG and Z. GAO, "Safety Demonstration Tests on HTR-10 Reactors", The 2-nd International Topical Meeting on High Suhue Reactor Technology, Beijing, China, September 22-24, (2004)

S. SHIOZAWA, S. FUJIKAWA, T. IYOKU, K. KUNITOMI, and Y. TACHIBANA, Overview of HTTR Design Features, Journal of Nuclear Engineering and Design, 233 (2004) 11

A. SEDOV, "Development of HTGR Technologies in Russia: Experiences, Activities, Plans", Meeting on the Planned PSI Research Project on HTR Graphite Dust Issues, Paul Scherrer Institute, Villigen, Switzerland, November 26-27, (2009)

V.P. GARIN, et al., Selection and Substantiation of an Annular Core Critical Assembly Configuration Simulating the PBMR Reactor Core at the ASTRA Facility, Russian Research Centre, Kurchatov Institute, Moscow, April (1999)

J.S. HENDRICKS, G.W. MCKINNEY, et al., MCNPX 2.6.0 Extensions, LA-UR-08-2216, Los Alamos National Laboratory, April 11, (2008)

M.B. CHADWICK, P. OBLOZINSKY, M. HERMAN, et al., ENDF/B-VII: Next Generation Evaluated Nuclear Data Library for Nuclear Science and Technology, Nuclear Data Sheets, Vol. 107 (2006) 2931

WILLIAM R. MARTIN, et al., An Advanced Neutronic Analysis Toolkit with In-line Monte Carlo Capability for VHTR Analysis, Final Report, DE-FC07-06 ID14745, University of Michigan, Department of Nuclear Engineering and Radiological Sciences, December, (2009) 